DOI: $10.20535 / 2410-8286.227831$

\title{
STRATEGIES FOR ORGANISING AND MANAGING RESEARCH AT UNIVERSITIES: SYSTEMIC REVIEW
}

\author{
Kateryna Shykhnenko \\ Institute of Public Administration and Research in Civil Protection, Kyiv, Ukraine \\ shikhkate@gmail.com
}

\author{
Alina Sbruieva \\ Sumy Makarenko State Pedagogical University, Sumy, Ukraine \\ sbruieva@gmail.com
}

\begin{abstract}
The purpose of the study was to identify and synthesise the interventions used to build the strategies for organising and managing research at universities that can be feasible in Ukraine. To achieve this purpose we provided a descriptive profile of the interventions and strategies used at universities to organise and manage research, rather than the detailed examination of substantive research results. The method of descriptive content analysis was applied to analyse empirical, experimental, review, conceptual, and commentary sources revealing strategies of organising and managing research at universities. The growth and corporate type strategies are dominant at universities, particularly in the USA and EU. The universities mainly seek cost-effective research opportunities that can help the institutions build a strong international brand. The policy of institutional strategic research management aimed at cooperation in research with other sectors seems to be the most feasible and appropriate for the Ukrainian research management context. Creating project management communities was found to be the second most feasible and appropriate strategy of organising and managing the university research in Ukraine. Financial criterion dominates in assessing the interventions for building a strategy of organising and managing research at universities. The university research can be stimulated at the state level through a demand-oriented reform that is aimed at reshaping the management of personnel, talent selection system, and personnel assessment.
\end{abstract}

Keywords: higher education; universities; university research; strategies for organising research; strategies for managing research.

\section{Introduction}

Strategies for organising and managing research have been increasingly important in building university research capacity at modern universities (Nguyen \& Meek, 2015). The problem of organising and managing the university research seems to be quite relevant for the context of the research at universities in Ukraine because this activity largely relies on the former Soviet regime-run model which stipulates that the research is conducted by separate, non-educational, government-funded entities (institutions) that form a closed research community with its 'rules of a game' and privileged researchers working full-time (Kiopa et al., 2016). As a result, the research activities and outputs fail to compete internationally, and attract direct investments, lack trust of the buyers of innovations, and accelerates the outflow of perspective junior researchers abroad. Throughout the recent decade, the government has been legally and finically encouraging higher education institutions to dedicate more efforts to research capacity making it a primary mission and thus improve the university research output (VRU, 2016). Given this, universities are looking for and adopting feasible and transferable international strategies of organising and managing research at universities in Ukraine. This created the gap to be addressed by the present systemic review.

\section{Literature review}

The strategies of organising and managing research at universities are revealed in the literature from the perspective of two key trends such as creating a strong brand for a university and transforming a university into a corporate business venture. These strategies are found to be strongly related to funding schemes. For example, performance funding is widely used in the Netherlands and the United Kingdom (UK). The tenders for research funding are commonly used in Japan and Germany. Matching grants are provided by business entities and governments in Canada, the Netherlands, and the UK. The schemes of full recovery of costs are widely used in the United States, Australia, the UK in allocation of research funding (Jung, 2012). Neither of the above schemes is found in the literature on higher education and research management in Ukraine.

The literature review found the categorisations of the university research strategies based on institutional goals and strategy types (Ahmed et al., 2015). The institutional goals-related strategies were as follows: growth strategies such as concentration, expansion, cooperation, internationalisation, and 
digitalisation; stability strategies; retrenchment strategies and the combination of the above strategies (Smith, 2011). These strategies seemed to be mainly directed outside the university. Concerning the type-based strategy categorisation, Robbins et al. (2018) specified three strategy types such as corporate, competitive, and functional. The corporate university research strategy seeks to identify scholarship types and areas of research within the institution. The competitive type of strategies relies on encouraging internal competition in the key scholarship areas between university departments or faculties or research teams. The functional type of strategy is meant to optimise operations and processes to increase the competitiveness of the institution. These strategies seemed to be mainly directed inside the university.

It seems obvious that the above university research strategies are based on substantial research funding and autonomy. Although the university autonomy is declared in Ukraine and there is only small-scale government funding of the research at universities and no radical change in the university research management model has occurred so far.

For that reason, the purpose of the study is to identify and synthesise the interventions used to build the strategies of organising and managing research at universities that can be feasible in Ukraine. To achieve this purpose we provided a descriptive profile of the interventions and strategies used at universities to organise and manage research, rather than the detailed examination of substantive research results.

\section{Methods and materials}

The method of descriptive content analysis was utilised to analyse empirical, experimental, review, conceptual, and commentary sources revealing strategies for organising and managing research at universities. The review process was organised to comply with relevant recommendations provided by Newman \& Gough (2020). It relied on a common set of processes such as specifying the research questions and methods, designing the conceptual framework, formulating the selection criteria and coding of the sources, developing the search strategy, evaluating the relevance and quality of the shortlisted papers, interpreting and reporting findings (Tsafnet et al., 2014). The search for the relevant sources was conducted in the Scientometric databases SCOPUS ${ }^{\circledR}$, WoS, bibliographic databases CrossRef and Google Scholar, and relevant international journals such as the Journal of Research Management and Administration, American Journal of Undergraduate Research, and Journal of Research Administration. The review process included five basic phases such as preparation, retrieval, appraisal, synthesis, and reporting. These phases pursued the goals of formulating the research questions and developing the review protocol, searching and de-duplicating the sources, shortlisting the sources for the retrieval or sending the requests to the authors for the full texts, examining and analysing the retrieved articles, and synthesising data addressing the research questions, and consolidating the finding to report them. Two research team members, the authors of this paper, were involved in the preparation, retrieval, and appraisal phases of the review process. Five experts were purposefully hired for the evaluation of the papers shortlisted for the final assessment. The checklist for the Preferred Reporting Items for Systematic reviews and Meta-Analyses for Protocols 2015 (PRISMA-P) was used to prepare the protocols for the systematic review (Moher et al., 2015). The Critical Appraisal Checklist (CAC) was designed to evaluate the literature sources throughout the retrieval and appraisal phases (see Appendix A). This was a modification of the 'Quality checklist for qualitative studies' borrowed from Greenhalgh et. al., (2005). It used a 4-point scale with 1 = "Not Relevant", 2 = "Somewhat Relevant", 3 = "Relevant", 4 = "Very Relevant". The coding sheets were used to assess each article. The Analytic Hierarchy Process (AHP) was applied in the final phase of the research.

The outline of the search strategy

The search strategy relied on the combinations of the keywords (Bethel \& Rogers, 2018; Papaioannou et al., 2009). This review was of a narrative type that was aimed at synthesising primary studies and evaluating them through description paying attention to what is already known about strategies of organising and managing research at universities and addressing practice issues of it. Several search strings based on English, Russian and Ukrainian languages were used for different databases. Below is presented the common search string.

$T I$ and/or $T W=($ strategies of research administrat $*$ at universities OR manag $*$ of research at universities $O R$ research policy at universities OR governance of the research at universities $O R$ reform of the research at universities $O R$ supervision research at universities $O R$ inspection of the research at universities) $A N D A B$ and/or $K W$ and/or ID (TITLE-ABS-KEY for SCOPUS) = (strategies OR manag* OR administrat* OR policy OR governance OR supervision OR reform of research at universities) AND CU $=U S A$ and/or Europe and/or Asia (WoS Categories: Social Sciences (subcategory: Education and 
Educational Research) And (Articles OR Reviews), Indexes: Social Science Citation Index 1988-present).

The criteria for evaluation of the sources that were selected for the review were as follows: 1) the article should be published between 2005-2020;2) it should highlight the strategies of organising and managing (administrating) research at universities in one of the regions such as the USA and/or Europe and/or Asia; 3 ) it should reveal the intervention with the described strategies of organising and managing (administrating) research at universities; 4) the strategy can be categorised based on the clear data. Following that, the Analytic Hierarchy Process (AHP) was used by five purposefully hired experts in educational research management to rate the feasibility and appropriateness for the Ukrainian context of the identified strategies of organising and managing research at universities.

\section{Experts}

3 experts were hired from the Institute of Public Administration and Research in Civil Protection (IPARCP) and 2 experts were hired from Sumy Makarenko State Pedagogical University (SMSPU). The criteria for selection were as follows: a) scientific background in either educational management or research management or research administration; b) sound scientific experience (proved by citations of their studies) in the field of their expertise; c) availability for our study.

The AHP was found applicable because it is widely used as the Multi-Criteria Decision-Making method (MCDMM) in management and research management (Taherdoost, 2017; Vargas, 2010). The criteria used in the prioritisation of interventions to build strategies for organising and managing research at universities were as follows: a) knowledge-generation and implementation; b) stakeholder commitment; c) financial; d) competitive advantage; e) other criteria. The two-level hierarchy of criteria for evaluating the above strategies developed by the authors is depicted in Figure 1.

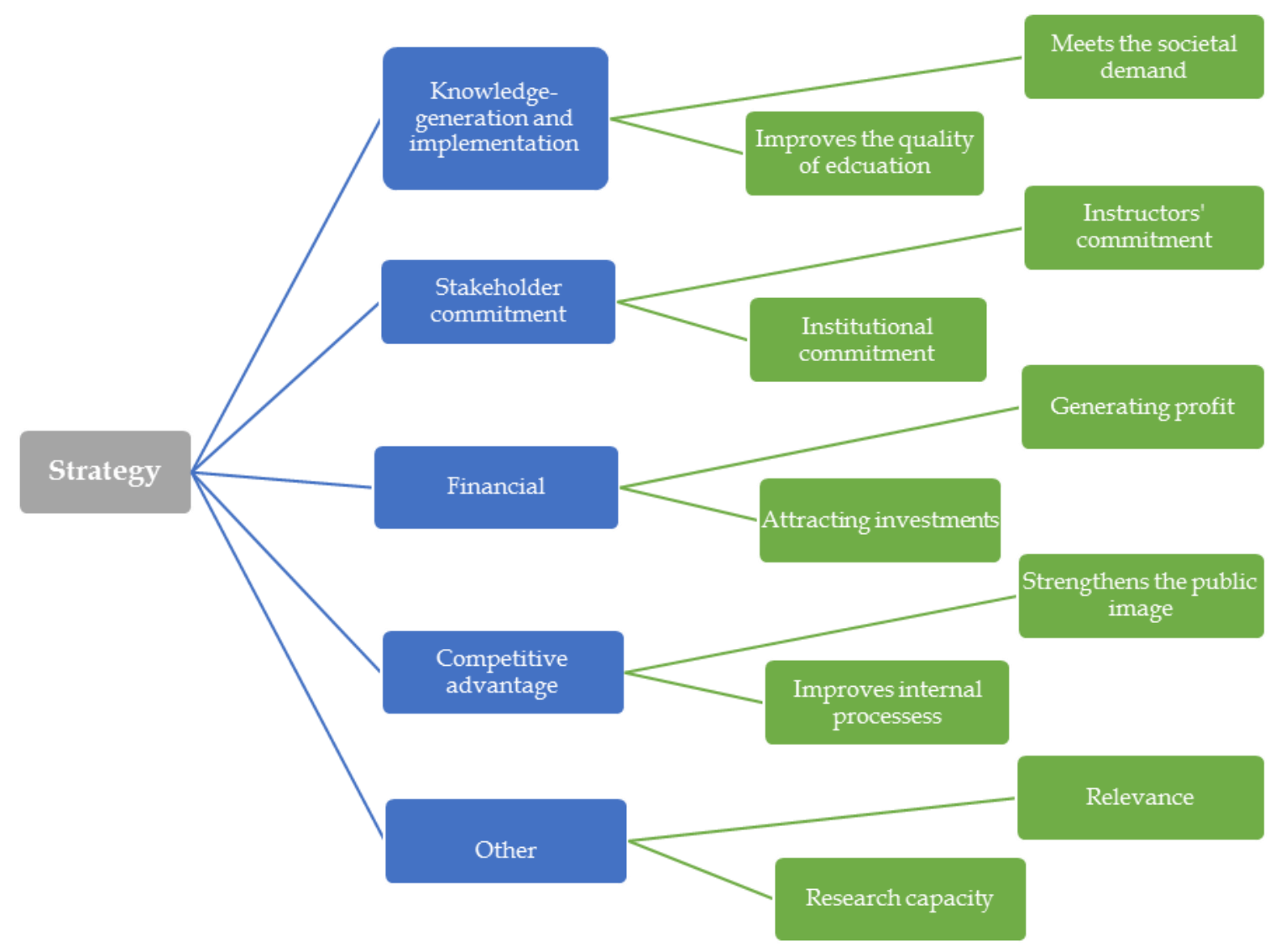

Figure 1: The two-level hierarchy of criteria for evaluating the strategies of organising and managing research at universities 
When the hierarchy of the criteria was specified, the comparison matrix was developed by the five mentioned above expert decision-makers. This began by determining the relative weight of the groups of criteria that are presented in Table 2. Saaty's (2008) Comparison Scale was employed. It was based on a comparison of two alternatives as it is the most widely used method for this purpose. The relative importance of one alternative when compared to the other one is determined numerically using the values from 1 to 9 by attributing these values to the specific alternative in a pair. The distribution of numerical and reciprocal values on the Saaty's (2008) Relative Importance Scale is shown in Table 1.

Table 1: Distribution of numerical and reciprocal values on the Saaty's Relative Importance Scale

\begin{tabular}{|l|c|c|}
\hline \multicolumn{1}{|c|}{ Relative Importance Scale } & Numerical values & Reciprocal values \\
\hline Extremely Preferred & 9 & $1 / 9$ \\
\hline Very strong to extremely & 8 & $1 / 8$ \\
\hline Very strongly preferred & 7 & $1 / 7$ \\
\hline Strongly to very strongly & 6 & $1 / 6$ \\
\hline Strongly preferred & 5 & $1 / 5$ \\
\hline Moderately to strongly & 4 & $1 / 4$ \\
\hline Moderately preferred & 3 & $1 / 3$ \\
\hline Equally to moderately & 2 & $1 / 2$ \\
\hline Equally preferred & 1 & $1 / 1$ \\
\hline
\end{tabular}

It is recommended that the evaluators use the odd numbers rather than the even ones to ensure that the measurement points are reasonably different. When an agreement can only be reached through negotiations, a middle point can be identified as a compromise (Saaty, 2009a).

Table 2: Relative weight of the groups of criteria

\begin{tabular}{|c|c|c|c|c|c|}
\hline Criteria group & KGI & SC & F & CA & OC \\
\hline KGI & 1 & $1 / 3$ & $1 / 9$ & $1 / 7$ & 1 \\
\hline SC & 3 & 1 & 1 & 1 & 5 \\
\hline F & 9 & 7 & 1 & 1 & 5 \\
\hline CA & 5 & 1 & $1 / 7$ & 1 & 5 \\
\hline OC & 1 & $1 / 5$ & $1 / 9$ & $1 / 7$ & 1 \\
\hline
\end{tabular}

Note: $\mathrm{KGI}=$ knowledge-generation and implementation; $\mathrm{SC}=$ stakeholder commitment; $\mathrm{F}=$ financial; $\mathrm{CA}=$ competitive advantage; $\mathrm{OC}=$ other criteria.

The relative weight of each criterion was calculated by dividing each table value by the total column value. The purpose of the calculation was to normalise the comparison matrix (see Table 3).

Table 3: Normalisation of the comparison matrix

\begin{tabular}{|c|c|c|c|c|c|}
\hline $\begin{array}{l}\text { Criteria } \\
\text { group }\end{array}$ & KGI & SC & F & CA & OC \\
\hline KGI & 1 & $1 / 3$ & $1 / 9$ & $1 / 7$ & 1 \\
\hline SC & 3 & 1 & 1 & 1 & 5 \\
\hline F & 9 & 7 & 1 & 1 & 5 \\
\hline CA & 5 & 1 & $1 / 7$ & 1 & 5 \\
\hline OC & 1 & $1 / 5$ & $1 / 9$ & $1 / 7$ & 17.00 \\
\hline Total & 19.00 & 9.53 & 2.36 & 3.28 & 0.058 \\
\hline \multicolumn{5}{|c|}{ Results } \\
\hline KGI & $1 / 19=0.052$ & 0.031 & 0.046 & 0.042 & 0.294 \\
\hline SC & $3 / 19=0.157$ & 0.104 & 0.423 & 0.304 & 0.294 \\
\hline F & $9 / 19=0.473$ & 0.734 & 0.423 & 0.304 & 0.294 \\
\hline CA & $5 / 19=0.263$ & 0.104 & 0.059 & 0.304 & 0.058 \\
\hline OC & $1 / 19=0.052$ & 0.020 & 0.046 & 0.042 & . \\
\hline
\end{tabular}

Note: $\mathrm{KGI}=$ knowledge-generation and implementation; $\mathrm{SC}=$ stakeholder commitment; $\mathrm{F}=$ financial; $\mathrm{CA}=$ competitive advantage; $\mathrm{OC}=$ other criteria. 
The obtained values were used for the experts' interpretation of the contribution of each criterion to the specified intervention to build the strategy of organising and managing research at universities (see Table 4). The priority vector (or Eigenvector) was then calculated to identify the input of each criterion. This calculation relied on the arithmetic average of all criteria.

Table 4: Results of calculation of the priority vector (or Eigenvector)

\begin{tabular}{|l|c|c|}
\hline Criteria group & Calculation & Eigenvector \\
\hline KGI & {$[0.052+0.031+0.046+0.042+0.058] / 5=0.0463$} & $4.63 \%$ \\
\hline SC & {$[0.157+0.104+0.423+0.304+0.294] / 5=0.2572$} & $25.72 \%$ \\
\hline F & {$[0.473+0.734+0.423+0.304+0.294] / 5=0.4466$} & $44.66 \%$ \\
\hline CA & {$[0.263+0.104+0.059+0.304+0.294] / 5=0.2057$} & $20.57 \%$ \\
\hline OC & {$[0.052+0.020+0.046+0.042+0.058] / 5=0.0442$} & $4.42 \%$ \\
\hline
\end{tabular}

Note: $\mathrm{KGI}=$ knowledge-generation and implementation; $\mathrm{SC}=$ stakeholder commitment; $\mathrm{F}=$ financial; $\mathrm{CA}=$ competitive advantage; $\mathrm{OC}=$ other criteria.

As can be seen in Table 4, the values found in the Eigenvector showed that the experts viewed the financial criterion as the most important for developing a strategy of organising and managing research at universities with its weight of $44.66 \%$. The criterion of the stakeholder commitment and criterion of the competitive advantage seemed to contribute to the strategy approximately twice as less as the financial one. Surprisingly, the knowledge-generation and implementation criterion was seen by the experts as the least important contributor to the strategy of organising and managing research at universities with its weight of $4.63 \%$.

\section{Instruments}

The Critical Appraisal Checklist (CAC) (Greenhalgh et al., 2005) and the Analytic Hierarchy Process (AHP) (Taherdoost, 2017) were used to analyse the data drawn from the literature sources. The CAC consisted of 9 questions (see Appendix A). The process of validation of the CAC showed that the Item-level content validity index (IL-CVI) was $<0.85$, the Kappa coefficient was $<0.83$, and the Scale-level content validity index (SL-CVI) was 92\%. The above values meant the CAC was valid. The Analytic Hierarchy Process (AHP) has been comprehensively validated in the literature (Asadabadi et al., 2019; Saardchom, 2012; Saaty, 2009b).

\section{Results}

The keywords-based search process is presented in a flow diagram (see Fig 2.)

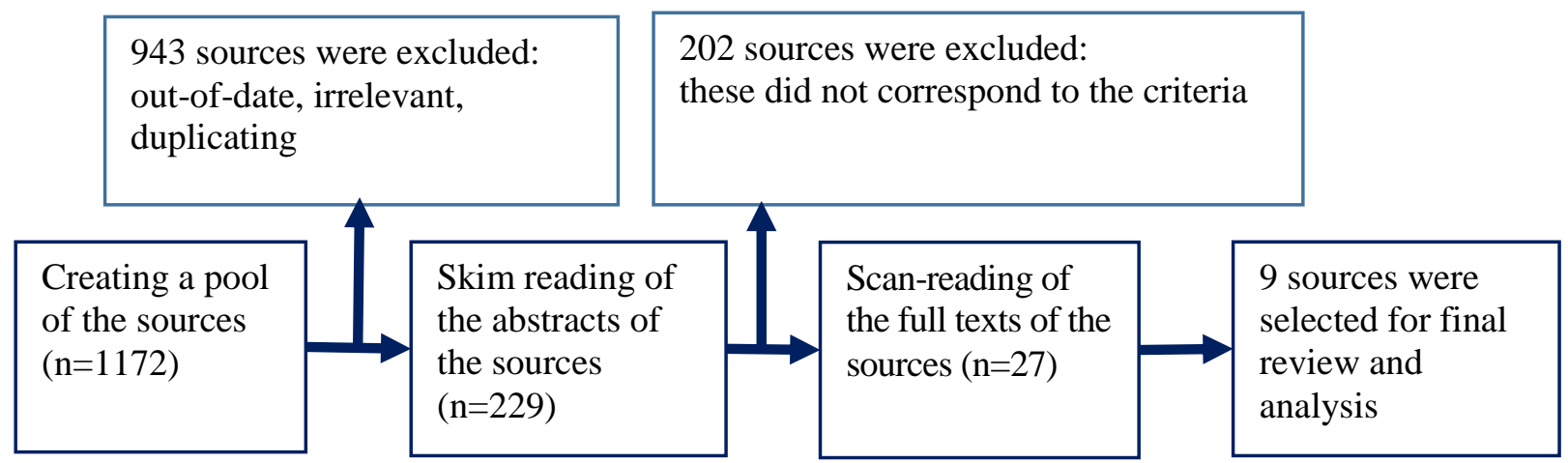

Figure 2: Keywords-based search process

The search found 9 eligible and relevant sources presenting interventions that were used to build the strategies of organising and managing research at universities that can be feasible in Ukraine (see results in Table 5). The interventions selected as feasible in Ukraine were as follows: a) collaborative research (CR); b) Supply Chain Management concept-based research (SCMRM) management; c) institutional strategic research management policy (ISRM); d) a project management community (PMC); e) a decentralised organisational structure of the university research management unit (DOS); f) an open innovation space 
approach (OISA); g) research clusters (RC); h) a research management and support systems project (RMSSP); i) a knowledge management-driven strategy (KMDS). As can be seen in Table 5, the interventions falling under the growth and corporate type strategies dominate at universities in different regions of the world. The review results presented in the effectiveness section of the table imply that universities mainly seek cost-effective research opportunities that can help the institutions build a strong international brand. The above suggests that institutions mainly from the developed countries (USA, EU) or emerging economies go international to get access to new sources of finance and new customers.

Table 5: Results of the analysis of the selected sources

\begin{tabular}{|c|c|c|c|c|c|}
\hline $\begin{array}{l}\text { Author(s), year } \\
\text { of publication }\end{array}$ & Intervention and description & $\begin{array}{c}\text { Category of } \\
\text { Strategy }\end{array}$ & Region & Effectiveness & $\begin{array}{l}\text { Mean } \\
\text { grade }\end{array}$ \\
\hline $\begin{array}{l}\text { 1) Arthur \& } \\
\text { Hodge, } 2013\end{array}$ & $\begin{array}{l}\text { Collaborative research } \\
\text { involving university, public } \\
\text { sector researchers, and } \\
\text { industry partners }\end{array}$ & $\begin{array}{l}\text { Corporate } \\
\text { type of } \\
\text { strategy }\end{array}$ & Australia & $\begin{array}{l}\text { Universities benefit from } \\
\text { participating in world-class } \\
\text { research, they save } \\
\text { financial resources for } \\
\text { research. Public sector } \\
\text { research organisations - } \\
\text { economise financial } \\
\text { resources and get access to } \\
\text { external researchers and } \\
\text { industry. Companies - get } \\
\text { access to research } \\
\text { capacities and use them } \\
\text { cost-effectively for a } \\
\text { commercial purpose }\end{array}$ & 3.3 \\
\hline $\begin{array}{l}\text { 2) Habib \& } \\
\text { Pathik, } 2012\end{array}$ & $\begin{array}{l}\text { Strategy based on the } \\
\text { Supply Chain Management } \\
\text { concept - incorporation of } \\
\text { benchmarking and value } \\
\text { enhancement tools in } \\
\text { education and research at } \\
\text { three levels - strategic level, } \\
\text { planning level, and } \\
\text { operating level }\end{array}$ & $\begin{array}{l}\text { Combination } \\
\text { of strategies } \\
\text { of growth, } \\
\text { stability, and } \\
\text { retrenchment }\end{array}$ & USA & $\begin{array}{l}\text { Benefits for both } \\
\text { individuals and society. } \\
\text { Brings welfare to the } \\
\text { students and wellbeing to } \\
\text { society }\end{array}$ & 3.4 \\
\hline $\begin{array}{l}\text { 3) Hazelkorn, } \\
2010\end{array}$ & $\begin{array}{l}\text { Institutional strategic } \\
\text { research management policy } \\
\text { - cooperating in research } \\
\text { with other sectors }\end{array}$ & $\begin{array}{l}\text { Corporate } \\
\text { type of } \\
\text { strategy }\end{array}$ & $\begin{array}{l}\text { Austria } \\
\text { (EU) }\end{array}$ & $\begin{array}{l}\text { Attracts funds for the } \\
\text { research, strengthens } \\
\text { international cooperation, } \\
\text { builds up a research } \\
\text { management system }\end{array}$ & 3.0 \\
\hline $\begin{array}{l}\text { 4) Johnson et } \\
\text { al., } 2020 \text {. }\end{array}$ & $\begin{array}{l}\text { A project management } \\
\text { community - consolidation } \\
\text { of efforts of internal and } \\
\text { external stakeholders and } \\
\text { fund providers at the } \\
\text { institutional level to conduct } \\
\text { the research and staff } \\
\text { development }\end{array}$ & $\begin{array}{l}\text { Growth } \\
\text { strategy }\end{array}$ & USA & $\begin{array}{l}\text { Effective for networking, } \\
\text { team science, and } \\
\text { professional development. } \\
\text { Promotes the institutional } \\
\text { brand. Serves as a proven } \\
\text { example of the sponsorship } \\
\text { model }\end{array}$ & 3.4 \\
\hline $\begin{array}{l}\text { 5) Nguyen \& } \\
\text { Meek, } 2015\end{array}$ & $\begin{array}{l}\text { Building a decentralised } \\
\text { organisational structure of } \\
\text { the university research } \\
\text { management structure - } \\
\text { based on the bottom-up- } \\
\text { approach to planning and } \\
\text { fulfilment of the research }\end{array}$ & $\begin{array}{l}\text { Functional } \\
\text { type of } \\
\text { strategy }\end{array}$ & Australia & $\begin{array}{l}\text { Builds the university } \\
\text { research capacity, } \\
\text { empowers researchers, and } \\
\text { increases university } \\
\text { research performance }\end{array}$ & 3.5 \\
\hline $\begin{array}{l}\text { 6) Saarela, } \\
2016\end{array}$ & $\begin{array}{l}\text { Open innovation space } \\
\text { approach - based on the } \\
\text { multidisciplinary action } \\
\text { learning and collaboration of } \\
\text { academicians, students, and } \\
\text { customers }\end{array}$ & $\begin{array}{l}\text { Corporate } \\
\text { type of } \\
\text { strategy }\end{array}$ & Finland & $\begin{array}{l}\text { Strengthens the public } \\
\text { image of the institution, } \\
\text { reshapes the curriculum, } \\
\text { intensifies the transfer of } \\
\text { tacit knowledge from the } \\
\text { employees to the students }\end{array}$ & 3.1 \\
\hline
\end{tabular}




\begin{tabular}{|c|c|c|c|c|c|}
\hline $\begin{array}{l}\text { 7) Sawahel, } \\
2019\end{array}$ & $\begin{array}{l}\text { Research clusters - unite } \\
\text { interested parties in the } \\
\text { research process }\end{array}$ & $\begin{array}{l}\text { Corporate } \\
\text { type of } \\
\text { strategy }\end{array}$ & $\begin{array}{c}\text { UK- } \\
\text { subsidised } \\
\text { programme } \\
\text { in Africa } \\
\end{array}$ & $\begin{array}{l}\text { Boosts access to funding } \\
\text { and increases the quality of } \\
\text { the research }\end{array}$ & 3.0 \\
\hline $\begin{array}{l}\text { 8) Wallis \& } \\
\text { Bates, } 2016\end{array}$ & $\begin{array}{l}\text { Research management and } \\
\text { support systems project }- \text { a } \\
\text { state-supervised initiative to } \\
\text { stimulate international } \\
\text { quality research activities } \\
\text { through the provision of } \\
\text { academic, administrative, } \\
\text { and financial support }\end{array}$ & $\begin{array}{l}\text { Growth } \\
\text { strategy }\end{array}$ & Africa & $\begin{array}{l}\text { Reshapes the research } \\
\text { strategies and policies at } \\
\text { the national level, promotes } \\
\text { the development of the } \\
\text { institutional support } \\
\text { services and research } \\
\text { infrastructure }\end{array}$ & 3.3 \\
\hline $\begin{array}{l}\text { 9) Watsilla \& } \\
\text { Vajjhala, } 2020\end{array}$ & $\begin{array}{l}\text { Knowledge management- } \\
\text { driven strategy involving } \\
\text { knowledge creation, } \\
\text { knowledge acquisition, and } \\
\text { knowledge of assimilation } \\
\text { processes }\end{array}$ & $\begin{array}{l}\text { Functional } \\
\text { type of } \\
\text { strategy }\end{array}$ & Africa & $\begin{array}{l}\text { Boosts the external } \\
\text { knowledge production } \\
\text { process and improves the } \\
\text { quality of students' } \\
\text { research }\end{array}$ & 3.2 \\
\hline
\end{tabular}

Figure 2 presents the consolidated priority results of rating the feasibility and appropriateness for the Ukrainian research management context of the identified interventions to build strategies of organising and managing research at universities using the Analytic Hierarchy Process (AHP) by five experts. The results were obtained after the calculation of all priorities and inconsistency indices. Figure 2 presents the averaged relative weight of each intervention based on the specified criteria in Fig. 1.

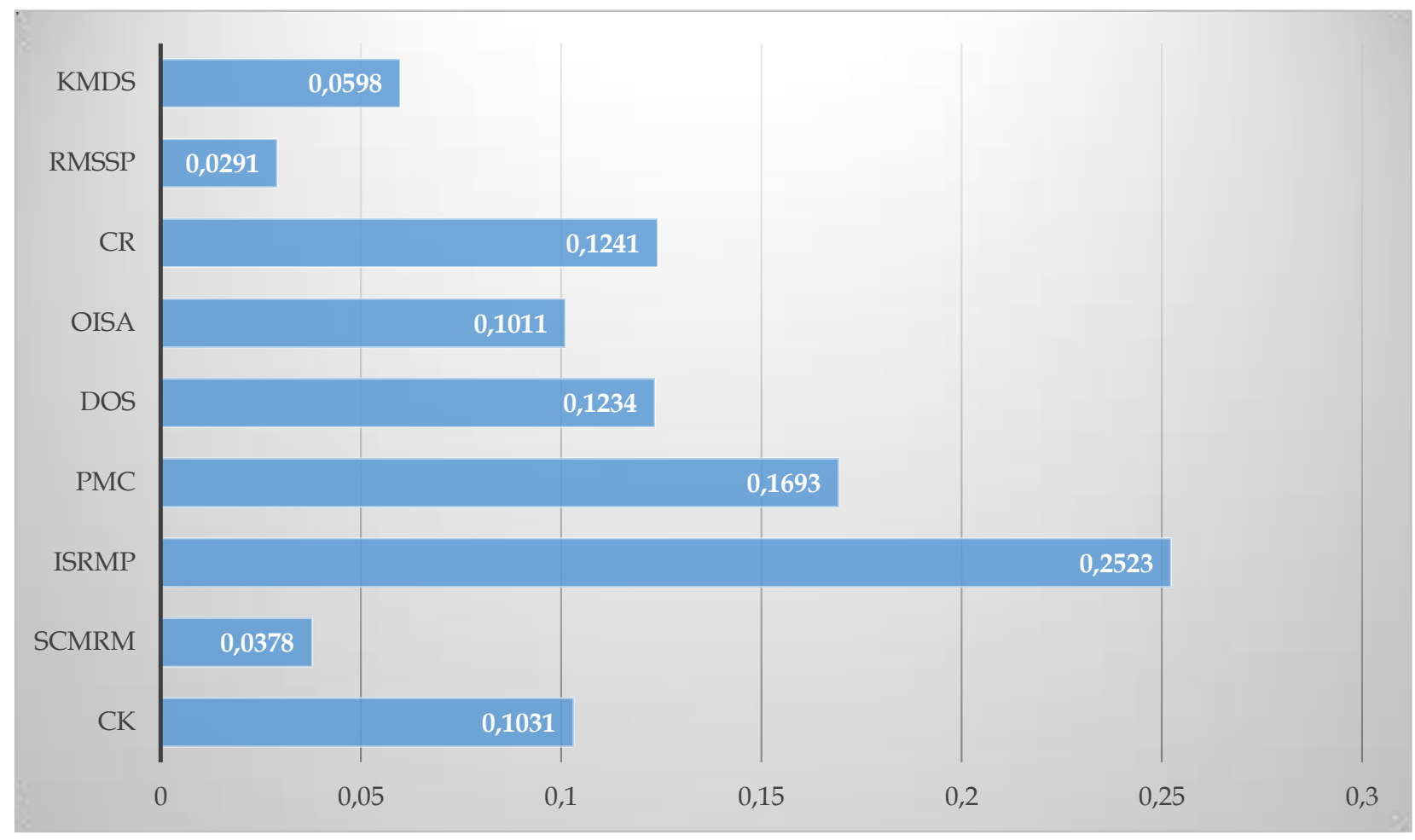

Note: $\mathrm{CR}=$ collaborative research; $\mathrm{SCMRM}=$ Supply Chain Management concept-based research management; ISRM = institutional strategic research management policy; PMC = Project management community; DOS = decentralised organisational structure of the university research management structure; OISA $=$ an open innovation space approach; RC $=$ research clusters; RMSSP = research management and support systems project; KMDS = knowledge management-driven strategy.

Figure 3: Consolidated priority results of rating the feasibility and appropriateness of the identified interventions to build strategies of organising and managing research at universities in Ukraine using the Analytic Hierarchy Process (AHP)

Figure 3 implies that the policy of institutional strategic research management aimed at research cooperation of universities with other sectors seems to be the most feasible and appropriate for the Ukrainian research management context. Creating project management communities was rated as the second most 
feasible and appropriate in Ukraine. Both collaborative research and an open innovation space approach were rated almost equally. Implementation of the research management and support systems project was rated as the least feasible and appropriate. Given the fact that financial criterion was identified as the most significant (see Table 4), RMSSP was found quite financially burdensome for the institution as it does not bring the added value but creates bureaucracy.

\section{Discussions}

The study sought to identify and synthesise the interventions used to build the strategies of organising and managing research at universities that can be feasible in Ukraine. According to the author's knowledge, no comprehensive review was carried out to address the problem of identifying the feasible interventions used to build the strategies of organising and managing research at universities in Ukraine. Although the reviewed works reveal the effectiveness of all the interventions in terms of strategic planning and building the institutional research capacity, none have assessed them from the perspective of their feasibility in the university context in Ukraine.

It was found that the interventions that were selected as feasible for universities in Ukraine were as follows: a) collaborative research (CR); b) Supply Chain Management concept-based research (SCMRM) management; c) institutional strategic research management policy (ISRM); d) A project management community (PMC); e) a decentralised organisational structure of the university research management structure (DOS); f) an open innovation space approach (OISA); g) research clusters (RC); h) a research management and support systems project (RMSSP); i) a knowledge management-driven strategy (KMDS). All of them have proven effective. Those interventions falling under the growth and corporate type strategies dominate at universities in different regions of the world. The review results presented in the effectiveness section of the table implied that universities mainly seek cost-effective research opportunities that can help the institutions build a strong international brand. The above suggests that institutions mainly from developed countries or emerging economies go international to get access to new sources of finance and new customers. The findings imply that the policy of institutional strategic research management aimed to cooperate in research with other sectors seemed to be the most feasible and appropriate for the Ukrainian research management context. Creating project management communities was rated as the second most feasible and appropriate in Ukraine. Both collaborative research and an open innovation space approach were rated almost equally. Implementation of the research management and support systems project was rated as the least feasible and appropriate. Given the fact that financial criterion was identified as the most significant, RMSSP was found quite financially burdensome for the institution as it is quite bureaucratic and does not create the added value.

The study agrees with the previous research, particularly with Tasir et al. (2016) who found that collaborative practices of researchers and professionals provide a more significant research output. Additionally, collaborative practices promote the creating of collaborative ventures at universities. Our study supports that of Derrick and Nickson (2014) who claimed that research management as an emerging occupation is still insufficiently described in terms of the successful strategies needed for this job. Based on our findings, we also totally agree with Qiu and Lu (2014) who argued that university research can be stimulated at the government level through a demand-oriented reform aimed at reshaping the management of personnel, talent selection system, and personnel assessment.

\section{Conclusion}

The growth and corporate type strategies are dominant at universities, particularly in the USA and EU. The universities mainly seek cost-effective research opportunities that can help the institutions build a strong international brand. The policy of institutional strategic research management whose purpose is to cooperate in research with other sectors seems to be the most feasible and appropriate for the Ukrainian research management context. Creating project management communities was found to be the second most feasible and appropriate in Ukraine for building the strategy of organising and managing the university research. Financial criterion dominates in assessing the interventions to build a strategy of organising and managing research at universities. The university research can be stimulated at the government level through a demandoriented reform that is aimed at reshaping the management of personnel, talent selection system, and personnel assessment.

Further research is needed into strategies at the system and institutional levels for managing efficient funding of the research at universities. 


\section{Acknowledgement}

We are grateful to experts for their commitment and persistence in the examination and analysis of the sources. The research was conducted within the scope of the Doctoral study in comparative higher education and is related to the project Erasmus + Jean Monnet Module "Europeanization of doctoral studies in the field of education: interdisciplinary and inclusive approaches" run in Sumy Makarenko State Pedagogical University, the Academic Coordinator is A. Sbruieva.

\section{Conflicts of Interest}

The author reports no conflict of interest of any nature.

\section{References:}

Ahmed, J. U., Ahmed, K. U., Shimul, A. S., \& Zuñiga, R. (2015). Managing Strategies for Higher Education Institutions in the UK. Higher Education for the Future, 2 (1), 32-48. https://doi.org/10.1177/2347631114558189

Arthur, J. F., \& Hodge, R. M. (2013). A model for managing intellectual property, commercialisation, and technology transfer within a collaborative research environment. International Journal of Economics and Management Engineering, 7(12), 3142$3245 . \quad$ https://publications.waset.org/9996853/a-model-for-managing-intellectual-property-commercialisation-andtechnology-transfer-within-a-collaborative-research-environment

Asadabadi, M. R., Chang, E., \& Saberi, M. |Zhou, Z. (Reviewing editor) (2019) Are MCDM methods useful? A critical review of the Analytic Hierarchy Process (AHP) and the Analytic Network Process (ANP). Cogent Engineering, 6(1), 1-11. https://doi.org/10.1080/23311916.2019.1623153

Bethel, A., \& Rogers, M. (2018). Choosing the right databases and search techniques. In P. Levay \& J. Craven (Eds.), Systematic Searching (pp. 73-94). Facet. https://doi.org/10.29085/9781783303755.005

Derrick, G., \& Nickson, A. (2014). Research management provides a balance between promoting the needs of institutions to meet their organisational objectives and the ability of academics to determine the best means of performing research. The Journal of Research Administration, 45(2), 11-45. https://eric.ed.gov/?id=EJ1157172

Greenhalgh, T., Robert, G., Bate, P., Macfarlane, F. \& Kyriakidou O. (2005). Critical Appraisal Checklists: Appendix 2. In T. Greenhalgh, G. Robert, P. Bate, F. Macfarlane \& O. Kyriakidou, Diffusion of Innovations in Health Service Organisations: A Systematic Literature Review (pp. 234-244). https://doi.org/10.1002/9780470987407.app2

Habib, M. \& Pathik, B. B. (2012). An investigation of education and research management for tertiary academic institutions. International Journal of Engineering Business Management, 4(1), 1-12. https://doi.org/10.5772/45735

Hazelkorn, E. (2010). Research strategy and management: University-based research in the knowledge economy. In J. Huisman and A.Pausits (eds.), Higher Education Management and Development(pp. 131-146). Compendium for Managers, Waxman Verlag GmbH, Münster

Johnson, M. R., Bolte, J., Veldman, T., \& Sutton, L. (2020). Establishing a project management community of practice in a large academic health system. Journal of Research Administration, 51(2), 102-110. https://www.srainternational.org/blogs/sraijra1/2020/09/29/establishing-a-project-management-community-of-pra

Jung, J. (2012). David D. Dill and Frans A. van Vught (Eds). National innovation and the academic research enterprise: public policy in the global perspective. Higher Education, 63, 383-385 https://doi.org/10.1007/s10734-011-9435-x

Kiopa, A., Schlicht, M., Sinclair, P., Szilágyi, L., Chang, H., Angelis, J., Nauwelaers, C., Posselt, T., \& Schuch, K. (2016). Peer review of the Ukrainian research and innovation system: Horizon 2020 Policy Support Facility. European Commission. https://rio.jrc.ec.europa.eu/sites/default/files/report/KI\%20AX\%2016\%20008\%20EN\%20N_UKR_0.pdf

Moher, D., Shamseer, L., Clarke, M., Ghersi, D., Liberati, A., Petticrew, M., Shekelle, P., Stewart, L. A., \& PRISMA-P Group (2015). Preferred reporting items for systematic review and meta-analysis protocols (PRISMA-P) 2015 statement. Systematic Review, 4(1), 1-9. https://doi.org/10.1186/2046-4053-4-1

Newman, M., \& Gough, D. (2020). Systematic Reviews in Educational Research: Methodology, Perspectives, and Application. In: Zawacki-Richter O., Kerres M., Bedenlier S., Bond M., Buntins K. (Eds.) Systematic Reviews in Educational Research. Springer VS, Wiesbaden. https://doi.org/10.1007/978-3-658-27602-7_1

Nguyen, H. \& Meek, V. L. (2015). Key considerations in organizing and structuring university research. Journal of Research Administration, (46) 1, 41-62. https://eric.ed.gov/?id=EJ1156089

Papaioannou, D., Sutton, A., Carroll, C., Booth, A., \& Wong, R. (2009). Literature searching for social science systematic reviews: consideration of a range of search techniques. Health Information \& Libraries Journal, 27(2), 114-122. https://doi.org/10.1111/j.1471-1842.2009.00863.x

Qiu, D., \& Lu, Y. (2014). Research on the evaluation of enterprise-university-research cooperation ability in Hubei Province. International Journal of Economics and Management Engineering, 8(6), 1724-1731. https://zenodo.org/record/1093185/files/9998503.pdf

Robbins, S., Bergman, R., \& Coulter, M. (2018). Management, $8^{\text {th }}$ edition. Pearson.

Saaty, T. L. (2008). Relative measurement and its generalization in decision making: Why pairwise comparisons are central in mathematics for the measurement of intangible factors. The Analytic Hierarchy/Network Process. Madrid: Review of the Royal Spanish Academy of Sciences, Series A, Mathematics, 102(2), 251-318. https://doi.org/10.1007/bf03191825

Saaty, T. L. (2009a). Extending the Measurement of Tangibles to Intangibles. International Journal of Information Technology \& Decision Making, 8 (1), 7-27. https://doi.org/10.1142/s0219622009003247

Saaty, R. (2009b). Validation Examples for the Analytic Hierarchy Process and the Analytic Network Process. In W. Adamus (Ed.), The Analytic Hierarchy and Network Processes: Application in Solving Multicriteria Decision Problems (pp. 39-62). Jagiellonian University Press.

Saardchom, N. (2012). The validation of the analytic hierarchy process (AHP) scoring model. International Journal of Liability and Scientific Enquiry, 5(2), 163-166. https://doi.org/10.1504/ijlse.2012.048472

Saarela, A-M. (2016). Making food science education and research activities more attractive for university students and food enterprises by utilizing an open innovative space approach. International Journal of Educational and Pedagogical 
Sciences, 10(1), 95-98. https://publications.waset.org/10003348/making-food-science-education-and-research-activitiesmore-attractive-for-university-students-and-food-enterprises-by-utilizing-open-innovative-space-approach

Sawahel, W. (2019). The study points to the importance of research management capacity. University World News. https://www.universityworldnews.com/post.php?story=20190709140805939

Smith, D. O. (2011). Managing the Research University. Oxford Scholarship Online. https://doi.org/10.1093/acprof:oso/9780199793259.001.0001

Taherdoost, H. (2017). Decision making using the analytic hierarchy process (AHP): A step by step approach. International Journal of Economics and Management Systems, 2, 1-4. https://ssrn.com/abstract=3224206

Tasir, Z., Kew, S. N., West, D., Abdullah, Z., \& Toohey D. (2016). Collaborative research between Malaysian and Australian universities on learning analytics: Challenges and Strategies. World Academy of Science, Engineering and Technology, Open Science Index 116, International Journal of Educational and Pedagogical Sciences, 10(8), 2900-2906. https://doi.org/10.5281/zenodo.1126211

Tsafnet, G., Glasziou, P., Choong, M. K., Dunn, A., Galgani, F. \& Coiera, E. (2014). Systematic review automation technologies. Systematic Reviews 3, 74. https://doi.org/10.1186/2046-4053-3-74

Vargas, R. V. (2010). Using the analytic hierarchy process (ahp) to select and prioritise projects in a portfolio. Project Management Institute. https://www.pmi.org/learning/library/analytic-hierarchy-process-prioritize-projects-6608

Verkhovna Rada Ukrainy (VRU) [Supreme Council of Ukraine]. (2016). Zakon Ukrainy "Pro naukovu i naukovo-tekhnichnu diialnist" vid 26 lystopada 2015 roku № 848-VIII [The Law of Ukraine "On Scientific and Scientific and Technical Activities” of November 26, 2015 (№ 848-VIII)]. Vidomosti Verkhovnoi Rady Ukrainy — Bulletin of the Verkhovna Rada of Ukraine, 3, 25. https://zakon.rada.gov.ua/laws/show/848-19 [in Ukrainian].

Wallis, S. \& Bates, I. (2016). Strengthening research management and support systems (RMSS) in African universities. Liverpool School of Tropical Medicine. https://www.lstmed.ac.uk/research/centres-and-units/capacity-research-unit-cru/ourprojects/strengthening-research-management

Watsilla, H. J., \& Vajjhala, N. R. (2020). Knowledge Management in Academic: A perspective of academic research contribution to the economic development of a nation. International Journal of Economics and Management Engineering, 14(3), 180-184. https://publications.waset.org/10011114/knowledge-management-in-academic-a-perspective-of-academic-researchcontribution-to-economic-development-of-a-nation 


\section{Appendix A}

Critical Appraisal Checklist (Greenhalgh et al., 2005)

Reviewer's ID

Date

Author(s) of the article/book

Year of publication

\section{Article ID}

\begin{tabular}{|c|c|c|c|c|c|}
\hline \multirow{2}{*}{ \# } & \multirow{2}{*}{ Question } & \multicolumn{4}{|c|}{ Scale } \\
\hline & & 1 & 2 & 3 & 4 \\
\hline 1 & Does the article reveal the problem related to one of the specified research question(s)? & & & & \\
\hline 2 & Do the strategies of organising and managing university research use the conceptual models? & & & & \\
\hline 3 & $\begin{array}{l}\text { Is the research output relevant to educators or university managers involved in organising and managing } \\
\text { university research? }\end{array}$ & & & & \\
\hline 4 & Are the strategies of organising and managing university research clearly explained? & & & & \\
\hline 5 & $\begin{array}{l}\text { Does the study provide a feasible plan of strategy implementation for organising and managing } \\
\text { university research? }\end{array}$ & & & & \\
\hline 6 & Does the study discuss actions taken from the perspective of different educational stakeholders? & & & & \\
\hline 7 & Are the results and effect size explained clearly? & & & & \\
\hline 8 & Is the research design transferrable? & & & & \\
\hline 9 & $\begin{array}{l}\text { Is the study congruent with the recent conceptual models of organising and managing university } \\
\text { research? }\end{array}$ & & & & \\
\hline
\end{tabular}

Note: 1 = "Not Relevant", 2 = "Somewhat Relevant", 3 = "Relevant", 4 = "Very Relevant"

Reviewer's Decision (underline): Eliminate Shortlist for detailed reading Shortlist for final review 